\title{
Sex Trafficking and Women - The Nigerian Experience
}

\author{
Ine Nnadi ${ }^{1}$ \\ 1 Faculty of Law, Imo State University, Owerri, Nigeria \\ Correspondence: Ine Nnadi, Faculty of Law, Imo State University, Owerri, Nigeria. Tel: 234-803-325-0809. \\ E-mail: inennadi2@yahoo.com
}

Received: May 17, 2013 Accepted: June 7, 2013 Online Published: August 30, 2013

doi:10.5539/jpl.v6n3p179 URL: http://dx.doi.org/10.5539/jpl.v6n3p179

\begin{abstract}
Sex trafficking is a type of violence perpetrated on women that takes place in diverse settings and usually involves many different actors. It is an aspect of human trafficking that is becoming pandemic in society and possibly, the fastest growing human rights violation in the world today. It has generated a lot of concern worldwide and especially in Nigeria where it is very rampant. Sex trafficking in females resembles the ancient dehumanizing slave trade. In most cases, it involves involuntary servitude and is therefore commonly referred to as modern day slavery. Sex trafficking thrives and goes on with impunity because several countries do not have tough anti-trafficking legislation in place and even when there are legislation in place, such laws are often not enforced to check the menace of sex trafficking due mainly to very influential people involved in this disgraceful act. Unfortunately few trafficking cases are prosecuted, and only a few actually result in convictions. What is more, fear and shame keep many women and girls from seeking help. Nigeria is one country that is deeply affected by sex trafficking and so has taken the bull by the horn by enacting a national law on human trafficking due to the high prevalence of sex trafficking in the country. This work examined the menace of sex trafficking particularly as it affects Nigeria and examined major legal framework in place to curb sex trafficking whilst ascertaining their adequacy or otherwise, and how the menace has been curtailed so far and proffered a solution.
\end{abstract}

Keywords: sex, human, trafficking, violence, women, Nigeria, legal framework

\section{Introduction}

Human trafficking is a heinous transnational crime undertaken by very highly organized and powerful syndicates. All sorts of antics are employed by the syndicates in the form of deceit, coercion on vulnerable girls whom they traffic overseas for domestic servitude and sexual exploitation.

Trafficking is modern-day slavery and has assumed the fastest growing criminal industry in the world. It is the recruitment, transportation, harbouring, or taking of people by means of threat, force, coercion, abduction, fraud, or deception for the purpose of exploiting them. Usually both men, and women, are bought and sold, sometimes many times over to work in brothels and other places overseas. It is also normal to see some of these trafficked persons being held in debt bondage and therefore expected to pay off the balance due to win their freedom from their supposed benefactors. Others, who may not have a debt to pay back, live more like prisoners as a result of threat to their lives.

Varied reasons have been canvassed for sex trafficking; poverty is a major reason for victims' vulnerability to it combined with in most cases lack of formal education as well as better job opportunities. In Nigeria, the economic situation is a direct cause of sex trafficking as in most cases both the parents and the girls trafficked are well aware of what they are entering into from the onset but due to the unemployment rate, low standard of living and the lack of basic social amenities, some still venture into it willingly.

The United Nations Protocol to Prevent, Suppress, and Punish Trafficking in Persons Especially Women and Children (Rossi 2000), defines trafficking as follows:

The recruitment, transportation, transfer, harbouring or receipt of persons by means of threat or use of force or other forms of coercion, of abduction, of fraud, of deception, of the abuse of power or of a position of vulnerability or of the giving or receiving of payments or benefits to achieve the consent of a person having control ... organs.

The United Nations estimates that 2.5 million people are trafficked annually. Sex trafficking deprives people of their human rights and freedoms, it is a global health risk, and it fuels organized crime. Victims of trafficking are 
forced or coerced into labor or sexual exploitation. Labor trafficking ranges from domestic servitude and small-scale labor operations to large-scale operations such as farms, sweetshops, and major multinational corporations.

This violation of human rights of the woman is also very rampant in Nigeria even though not restricted to it, as the huge cry globally suggest its presence everywhere. No country in the world is exempted in this violation, as countries provide points where girls are either imported from or eventually exported to.

Because of its pervasive nature, since 2000 the United States Department of State has issued the world's most comprehensive annual report on trafficking and the latest report calculates that 600,000 to 800,000 human beings are trafficked across international borders each year and these figures do not account for those who are trafficked "internally" from one destination to another within their own countries or communities. The report further estimates that $80 \%$ of transnational victims are women and girls and most of them are trafficked into commercial sex industry (Note 1).

According to the International Labour Organization, (Geneva, 2005), this industry "has become highly diversified and global in recent years." On its part, the United Nations Commission on the Status of Women Oral Statement on Eradicating Commercial Sexual Exploitation said:

Commercial sexual exploitation of women and girls of all ages, including prostitution, pornography, the internet bride industry and sex tourism, is one of the most devastating and escalating practices of gender-based violence assaulting the human rights and dignity of women and girls. No society that purports to uphold gender equality should tolerate and accept the sexual commoditization of women and girls. (Note 2)

The authors of Broken Bodies Broken Dreams (IRIN, 2005) opined that:

Every year, thousands of Nigerian women are trafficked into Western Europe and forced to work in the sex industry to pay back up to $\$ 50,000$...

Sex trafficking is not only immoral, it is also an offence under the law, however even in the face of several international instruments against trafficking, the act has gone on unabated in many places. A worrisome development in sex trafficking is the fact that, it is growing in leaps and bounds in rapid proportion in Nigeria and is likely to remain an under reported violation of human rights of women due to the secrecy involved in the business. In the face of this, the work will examine sex trafficking in Nigeria and the legal regime in place to curb the menace in the country as well as its impact so far.

\section{Overview of Sex Trafficking}

Indeed it is obvious that sex trafficking is assuming a greater dimension with increasing numbers of countries entering into the dehumanizing business. Globalization has created an enabling environment facilitating the activities of traffickers to transport victims between countries with relative ease. The menace of sex trafficking even though a major concern in Nigeria, is a widespread global problem of monumental scope, implicating nearly every country in the world.

According to a report on Trafficking in Persons: Global Patterns, published by the United Nations Office on Drugs and Crime (UNODC, 2006), Governments need to get serious about identifying the full extent of the problem so they can get serious about eliminating it. (Gbadamosi, 2006), states that the fact that this form of slavery still exists in the 21 st century shames us all. The truth is that, there is hardly any country in the world that is not implicated in the crime of human trafficking for sexual exploitation or forced labour. The report therefore identified 127 countries of origin, 98 transit countries, and 137 destination countries. Nigeria is a source, transit and destination country for trafficked women and children who are usually trafficked to Europe.

The fact remains that trafficking in human beings especially women and girls is not new, it is traceable to pre-historic times, indeed it has taken many forms, but in the context of modern globalization, it has acquired shocking new dimensions. In modern times, it has become a complex, multi-facetted phenomenon involving multiple stakeholders at the institutional and commercial level. (Note 3). It is one heinous practice that continues to proliferate at an alarming rate and has a particular relevance to women and girls.

The last two decades have seen an increase in the domestic trafficking of Nigerian women and children, and internationally, Nigerian women are trafficked to all parts of the world. Presently, there is an obvious and fast evolving trend in the trafficking of Nigerian women and young girls to the United Kingdom to work as domestic servants. Indeed it is now a common fact that a huge number of girls claiming asylum in the United Kingdom are actually trafficked persons. It is also of common knowledge that Nigerian women and children whether 
trafficked internally or externally are usually trafficked for sex. This violence against the woman and girl, in the last decade had seen thousands of women and young girls trafficked into the sex industry especially into Europe. The rate of trafficking soared so much that, so many Nigerians equate trafficking with prostitution alone and not other forms of labour which are also prevalent. The fact is that, the factors that make women and girls particularly vulnerable are rooted in systematic gender discrimination especially devaluation of women and children's human rights.

Italy is one country where women and girls are trafficked very frequently. Trafficking of persons in Italy comprises of adults and minors who are usually trafficked for sexual purposes. Unfortunately Nigeria serves as a major country of origin for women and girls who are sold into prostitution in Italy.(Note 4). It has been observed that the highest numbers of trafficked women and girls into Italy come from Nigeria and the trend has continued to grow. Agatise, (2011), posits that a smaller number of women and girls originate from Kenya, Ghana, and Ivory Coast, that the insidious nature of sex trafficking of women has Nigeria recording about 65 percent of persons trafficked into prostitution in Italy and of that number 85 percent are from the Edo ethnic group of Nigeria. Usually these women from Nigeria are promised fantastic well paid jobs in Europe, in factories, offices, and farms. They however arrive in Italy only to find themselves sold into sexual slavery and forced prostitution to payback the so called debts which supposedly was incurred in bringing them to Europe.

Because of the huge profit made in this debasing act, sex trafficking has become one of the most profitable forms of trafficking since it involves sexual prostitution, pornography, bride trafficking, and the commercial sexual abuse of children.

Sex trafficking of women in the world became so rampant that several non-governmental organizations and groups including several governments of different countries have joined the United Nations in advocating for laws that will combat trafficking in women. One of such nongovernmental organizations is the Coalition against Trafficking in Women International. CATW promotes the human rights of women by working internationally to combat all forms of sexual exploitation particularly sex trafficking of women and girls.

It is now apparent that Nigeria is a source, transit, and destination country for women and children subjected to trafficking in persons. (Note 5). Nigerian women and children trafficked are mostly recruited from rural communities within the country's borders, for involuntary domestic servitude and forced commercial sexual exploitation in foreign countries. Conversely, children from other parts of West Africa like Benin, Ghana and Togo are also trafficked in Nigeria as well.

In present times, sex trafficking has become a very serious form of organized crime globally that involves the exploitation of women and girls by very powerful syndicates. In Nigeria the menace of trafficking is becoming pandemic but it is very difficult to know the exact number of people who are trafficked each year due partly to inefficient data collating system and under-reporting. There is also the lack of synergy between the different law enforcement agencies the Police, Customs, Immigration, and NAPTIP officials involved in curbing sex trafficking in the country.

Bearing their thoughts on the subject, (Egede, et al., 2009) observed that although men, women, boys and girls can be trafficked, the crime of sex trafficking is not gender neutral; gender dimensions of trafficking are to be found throughout the trafficking process. They emphasized that the push factors affect both men and women, but women and girls experience them disproportionately. It is necessary to point out that prostitution is a common industry in which most trafficked persons are forced to work. Children who are trafficked within Nigeria are most of the times also pushed into forced or domestic labour or prostitution.

Sex trafficking takes place in both public and private places. In several cases, trafficking women openly engage in street-level prostitution besides hotels without concealing their identity, but in most cases, sex trafficking takes place in underground venues, such as private homes or brothels. Often, public and legal locations such as massage parlors, spas and strip clubs will be a front for illegal prostitution and trafficking (Note 6).

Occasionally though, women and girls who have been forced into prostitution are rescued from traffickers and receive support, care and compassion. More often, though, trafficking victims are treated like criminals by the police. Women and girls arrested in trafficking circles are often processed as illegal immigrants in foreign countries, rather than trafficking victims, and are immediately deported to their home countries where, because few economic alternatives exist in most cases, some begin the cycle of trafficking and exploitation all over again.

Recently in Nigeria, it was reported in Imo State (Horn Newspaper, May 2013), how young girls were kept in an enclosed house, and a young man was contracted to have sexual intercourse with them and make them pregnant. The story went on to say that, babies from the girls were sold by the owner of the home for exorbitant prices 
depending on the sex of the child and the girls in turn were given paltry sums for their suffering and sexual slavery. This story shocked the entire state as it was unheard of that a 21 year old man could be contracted to make 17 teenage girls pregnant at the same time for money.

\section{Legal Framework against Trafficking in Nigeria}

As adumbrated earlier, Nigeria has taken the bull by the horn in tackling the issue of sex trafficking in this country. The Government of Nigeria fully complies with the minimum standards for the elimination of trafficking in combating human trafficking.

As a result of the monotonous nature of trafficking both internally and externally, the Federal Government of Nigeria took a strong stand against trafficking and treated it as a priority criminal justice issue. In 2003 the Federal Government passed the Trafficking in Persons (Prohibition) Law (Enforcement) And Administration Act 2003 (Note 7), which established the National Agency for Prohibition of Trafficking in Persons and Other Related Matters 26th August, 2003. The NAPTIP Act is operational throughout the country. It is a major instrument in Nigeria tackling trafficking of women and girls for prostitution. Apart from establishing the NAPTIP, the NAPTIP Act criminalizes crimes that are connected to, or part of human trafficking, moreover it sets out requirements for the protection of trafficked persons. This Act is a major domestic legislation in Nigeria intended to protect women and girls from violence. It made provisions for tackling sex trafficking and for ease of reference, i shall reproduce the relevant sections as follows;

Section 11. Exportation of any person out of Nigeria and importation of persons into Nigeria

Any person who-

(a) exports from Nigeria to any place outside Nigeria any person under the age of eighteen years with intent that such person, or knowing it to be likely that such person will be forced or seduced into prostitution in that place; or

(b) imports into Nigeria from any place outside Nigeria, any person under the age of eighteen years with the intent that may be, or knowing it to be likely that such person will be forced into prostitution anywhere in Nigeria.

Section 12. Procurement of any person

Any person who-

(a) by use of deception, coercion, debt bondage or any means whatsoever induces any person under the age of eighteen years to go from one place to another to do any act with intent that such person, may be, or knowing that it is likely that the person will be forced or seduced into illicit intercourse with another person; or

(b) in order to gratify the passions of another person, procures, entices or leads away, even with such person's consent, any person under the age of eighteen years,

commits an offence and is liable on conviction to imprisonment for ten years without an option of fine.

Section 13. Causing or encouraging the seduction or prostitution of any person under eighteen years

(1) Any person who, having the custody, charge or care of any person under the age of eighteen years, causes or encourages the seduction, unlawful carnal knowledge or prostitution of, or the commission of an indecent assault upon any person, commits an offence and is liable on conviction to imprisonment for ten years.

(2) A person shall be deemed to have caused or encouraged the seduction, unlawful carnal knowledge or prostitution of or the commission of indecent assaults upon any person who has been seduced, unlawfully carnally known, or indecently assaulted, or who has become a prostitute, if he knowingly allows such person to consort with, or to enter or continue in the employment of, any prostitute or person of known immoral character.

Section 14. Procurement of any person under eighteen years

(1) Any person who procures a person who is under the age of eighteen years to have unlawful carnal knowledge with any other person or persons, either in Nigeria or any place outside Nigeria, commits an offence and shall be liable on conviction to imprisonment for ten years.

(2) Any person who procures any person under the age of eighteen years to-

(a) become a prostitute, either in Nigeria, or any place outside Nigeria; 
(b) leave Nigeria with intent that such person may become a prostitute in any place outside Nigeria;

(c)leave such person's usual place of abode in Nigeria, with intent that such person engage in prostitution either in Nigeria or any place outside Nigeria,

commits an offence and is liable on conviction to imprisonment for ten years.

Section15. Procurement of any person for prostitution, pornography and use in armed conflict

Any person who-

(a) procures, uses or offers any person for prostitution, or the production of pornography, or for pornographic performance;

(b) keeps a brothel;

(c) allows a person under the age of eighteen years to be in a brothel or trades in prostitution;

commits an offence and is liable on conviction to imprisonment for fourteen years without an option of fine.

Victim protection is central to combating trafficking effectively; accordingly the Act provides certain reliefs for victims of trafficking. For instance section 50 of the Act provides that the agency shall ensure that:

(a) A trafficked person is not subjected to discriminatory treatment in practice on account of race, colour, sex, age, language, religion, political or other opinion, cultural beliefs or practices, national, ethnic or social origin, property, birth or other status, including his status as a victim of trafficking or having worked in the sex industry.

Section 50 in its subsections has a number of reliefs that can properly be seen as protecting women against violence in the society.

Section $50(\mathrm{~b})$

A trafficked person has access to adequate health and other social services during the period of temporary residence;

(c) A trafficked person has access to the embassy or consulate of the country of which he is a citizen or where there is no embassy or consulate, ensure access to the diplomatic representative of the state that takes charge of the country's interest or any national to protect him;

(d) A trafficked person is able to return home safely, if he so wishes and when he is able to do so;

(e) A trafficked person is not denied temporary residence visas during the pendency of any criminal, civil or other legal actions;

(f) Investigation, detection, gathering and interpretation of evidence are conducted in such a manner as to minimise intrusion into the personal history of a trafficked person;

(g) The identity of a person trafficked is protected;

(h) the use by any person's history of being trafficked to discriminate or cause harm to any trafficked person his family or his friends in any way whatsoever, particularly with regards to freedom of movement, marriage or search for gainful employment is not encouraged;

(i) It takes steps to maintain and rehabilitate facilities provided for trafficked person; and

(j) A trafficked person and his family if protected from intimidation, threats, and reprisals from traffickers and their associates including reprisals from person in position of authority.

Sections 51 and 52 are also relevant in the protection of violated persons. For ease of reference Sections 51 and 52 are hereby reproduced as follows;

Section 51. Non-detention or presentation of a trafficked person in certain circumstances:

Where the circumstances so justify, trafficked persons shall not be detained, imprisoned or prosecuted for offences relating to being a victim of trafficking, including non-possession of a valid travel stay or use of a false travel or other document.

52. Right to institute civil action

A trafficked person, irrespective of his immigration status- 
(a) has the right to institute civil action against a trafficker and any other person including a public officer who has exploited or abused him; and

(b) is entitled to compensation, restitution and recovery for economic, physical and psychological damages to be met from the assets if any of the convicted trafficker forfeited and paid to the Victims of Trafficking Trust Fund.

The 2003 Trafficking in Persons Law Enforcement and Administration Act was amended in 2005 to increase penalties for trafficking offenders; it also prohibits all forms of human trafficking. The law prescribed penalties of five years imprisonment and/or a $\$ 670$ fine for labor trafficking, 10 years' imprisonment for trafficking of children for forced begging or hawking, and 10 years to life imprisonment for sex trafficking. These penalties even though sufficiently stringent and commensurate with penalties prescribed for other serious crimes, such as rape, have however not curbed the menace of sex trafficking remarkably.

The Criminal Code is another statute that deals with sex trafficking. Under the Criminal Code, the offence of Procuration deals with sex trafficking in some respects. Section 222-255 of the Criminal Code provide as follows;

222. Indecent treatment of girls under sixteen;

Any person who unlawfully and indecently deals with a girl under the age of sixteen years is guilty of a misdemeanour, and is liable to imprisonment for two years, with or without caning.

If the girl is under the age of thirteen years, he is guilty of a felony and is liable to imprisonment for three years, with or without caning.

It is a defence to a charge of the offence defined in this section to prove that the accused person believed, on reasonable grounds, that the girl was of or above the age of sixteen years.

The term "deal with" includes doing any act which, if done without consent, would constitute an assault as hereinafter defined.

\section{A. Causing or encouraging the seduction or prostitution of a girl under sixteen}

(1) Whoever, having the custody, charge or care of a girl under the age of sixteen years, causes or encourages the seduction, unlawful carnal knowledge or prostitution of, or the commission of an indecent assault upon, such a girl, shall be liable to imprisonment for two years.

(2) For the purposes of this section, a person shall be deemed to have caused or encouraged the seduction, unlawful carnal knowledge or prostitution of, or the commission of an indecent assault upon, a girl who has been seduced, unlawfully carnally known, or indecently assaulted, or who has become a prostitute, if he has knowingly allowed her to consort with, or to enter or continue in the employment of, any prostitute or person of known immoral character.

On its part, section 223 provides that; any person who;

(1) procures a girl or woman who is under the age of eighteen years to have unlawful carnal connection with any other person or persons either in Nigeria or elsewhere; or

(2) procures a woman or girl to become a common prostitute either in Nigeria or elsewhere; or

(3) procures a woman or girl to leave Nigeria with intent that she may become an inmate of a brothel elsewhere; or

(4) procures a woman or girl to leave her usual place of abode in Nigeria, with intent that she may, for the purposes of prostitution, become an inmate of a brothel either in Nigeria or elsewhere,

is guilty of a misdemeanour and is liable to imprisonment for two years.

A person cannot be convicted of any of the offences defined in this section of this Code upon the uncorroborated testimony of one witness.

The offender may be arrested without warrant.

224. Procuring defilement of woman by threats or fraud, or administering drugs

Any person who-

(1) by threats or intimidation of any kind procures a woman or girl, to have unlawful carnal connection with a man either in Nigeria or elsewhere; or 
(2) by any false pretence procures a woman or girl to have unlawful carnal connection with a man either in Nigeria or elsewhere; or

(3) administers to a woman or girl, or causes a woman or girl, to take, any drug or other thing with intent to stupefy or overpower her in order to enable any man, whether a particular man or not, to have unlawful carnal knowledge of her, is guilty of a misdemeanour and is liable to imprisonment for two years.

A person cannot be convicted of any of the offences defined in this section upon the uncorroborated testimony of one witness.

225. Abduction of a girl under eighteen with intent to have carnal knowledge:

Any person who, with intent that an unmarried girl under the age of eighteen years may be unlawfully carnally known by any man, whether a particular man or not, takes her or causes her to be taken out of the custody or protection of her father or mother, or other person having the lawful care or charge of her, and against the will of such father or mother or other person, is guilty of a misdemeanour and is liable to imprisonment for two years.

It is a defence to a charge of any of the offences defined in this section of this Code to prove that the accused person believed, on reasonable grounds, that the girl was of or above the age of eighteen years.

225A. Persons trading in prostitution (1) Every male person who;

(a) knowingly lives wholly or in part on the earnings of prostitution; or

(b) in any public place persistently solicits or importunes for immoral purposes,

is liable to imprisonment for two years, and in the case of a second or subsequent conviction, shall, in addition to any term of imprisonment awarded, be liable to caning.

(2) b bbnnAny magistrate who is satisfied, by evidence upon oath, that there is reason to suspect that any premises or any part of any premises are or is used by a female for purposes of prostitution, and that any male person residing in or frequenting the premises is living wholly or in part of the earnings of the prostitute, may issue a warrant under his hand authorising any constable to enter and search the premises and to arrest that male person.

(3) Where a male person is proved to live with or to be habitually in the company of a prostitute or is proved to have exercised control, direction, or influence over the movements of a prostitute in such a manner as to show that he is aiding, abetting, or compelling her prostitution with any other person or generally, he shall, unless he can satisfy the court to the contrary, be deemed to be knowingly living on the earnings of prostitution.

(4) Every female who is proved to have, for the purposes of gain, exercised control, direction or influence over the movements of a prostitute in such a manner as to show that she is aiding, abetting or compelling her prostitution with any person or generally, is liable to imprisonment for two years.

Other Sections such as, 227, 365, 366 and 369 of the Criminal Code can also be used to prosecute cases of human trafficking and invariably sex trafficking.

Edo State of Nigeria has very high incidence of women trafficked into prostitution overseas and as a result of the high number, Edo State amended the state Criminal Code to strengthen traffic related offences. (Note 8)

The Child Rights Act 2003 in Nigeria also criminalizes child trafficking, despite the fact that only a few of the States out of the country's 36 states, including the Federal Capital Territory, have enacted it. Section 30 provides as follows;

Prohibition of buying, selling, hiring or otherwise dealing in children for the purpose of hawking or begging for alms or prostitution, etc (Note. 9).

(1) No person shall buy, sell, hire, let on hire, dispose of or obtain possession of or otherwise deal in a child.

(2) A child shall not be used-

(a) for the purpose of begging for alms, guiding beggars, prostitution, domestic or sexual labour or for any unlawful or immoral purpose ; or

(b) as a slave or for practices similar to slavery such as sale or trafficking of the child, debt bondage or serfdom and forced or compulsory labour; . 
(e) procured or offered for prostitution or for the production of pornography or for any pornographic performance; and

(3) A person who contravenes the provisions of subsection (1) of this section commits an offence and is liable on conviction to imprisonment for a term of ten years.

Section 32 also provides for other forms of sexual abuse and exploitation of a child which invariably applies to the girl-child.

\section{Forms of sexual abuse and exploitation}

(1) A person who sexually abuses or sexually exploits a child in any manner not already mentioned under this Part of this Act commits an offence.

(2) A person who commits an offence under subsection (1) of this section is liable on conviction to imprisonment for a term of fourteen years.

The Act further provides; every child is entitled to respect for the dignity of his person, and accordingly, no child shall be subjected to physical, mental or emotional injury, abuse, neglect or maltreatment, including sexual abuse, torture, inhuman or degrading treatment or punishment; held in slavery or servitude etc.(Note 10)

The Penal Code which is applicable in Northern Nigeria also contains similar provisions that can be used in punishing the offence of sex trafficking of women and girls for immoral purposes or sexual exploitation. The relevant provisions of the Penal Code on Human Trafficking are as follows: Section 275 provides;

Whoever by any means whatsoever, induces a girl under the age of eighteen years to go from any place or to do an act with intent that the girl may be, or knowing, that it is likely that she will be forced or seduced to illicit intercourse with another person shall be punished with imprisonment which may extend to ten years and shall be liable to a fine.

Section 278 provides that any person who buys, sells, hires, lets to hire or otherwise obtains possession or disposes of any person below 18 years with intent that the person will be or is likely to be employed or used for prostitution or other unlawful or immoral purposes is guilty of an offence punishable with imprisonment of up to ten years and liable to pay a fine in addition.

Section 279 creates the offence of slave dealing and provides that any person who imports, exports, removes, buys, sells, disposes of, traffics or deals in any person as a slave or accepts, receives or detains such person is liable to imprisonment for a maximum of 14 years and a fine.

Section 280 punishes forced labour with a fine and a year's imprisonment.

Section 281 punishes the procurement, enticement, or leading away of any woman or girl (with or without her consent) for immoral purpose with imprisonment of up to 7 years and a fine.

The Immigration Act is another statute in Nigeria that deals with trafficking. Section (1)(g-h) frowns at brothel keepers and householders, who permit the defilement of young girl on his premises, persons, encouraging the seduction or prostitution of girl under thirteen years of age, person trading in prostitution or a procurer. If such a person is not a Nigerian, he is liable to be declared a prohibited immigrant and deported out of Nigeria.

\section{Conclusion}

Trafficking in persons has become the largest manifestation of slavery in present times depriving people of their rights and fundamental freedoms. It is a threat to global development, safety, and peace. Indeed trafficking is harmful to the individual trafficked as well as to society at large.

Trafficking has assumed a multi-dimensional problem troubling the world at large. Human trafficking for whatever purpose impacts negatively on the lives of the victims. Trafficking undermines public health of victims; they suffer various physical, psychological, and sexual abuses. Sexual abuses of victims result in reproductive health problems such as sexually transmitted infections (STIs) including HIV/AIDS. Sex trafficking is inherently demeaning, harmful and indeed violates the fundamental human rights to life, liberty, dignity and freedom from discrimination.

Basically factors that influence trafficking include poverty, urbanization, gender inequalities in society. The unfortunate thing about sex trafficking of women is that, invariably, most of these girls end up contacting the HIV/AIDS virus and die in the process after being subjected to very dehumanizing and debasing violence and an onslaught on their human dignity. Indeed sex trafficking is incompatible with the worth and dignity of women. 
It is true that Nigeria largely affected by this pandemic violation of human rights of women has several, legislation on trafficking but the truth is that, despite all the laws in place, the menace is still very prevalent in Nigeria. A number of reasons can be adduced for this prevalence of sex trafficking. First, the lack of synergy between the agencies who should implement the law; the Police, Customs, Immigration, and NAPTIP officials. For instance, poor networking between the different agencies in cases of sex trafficking.

Second, beyond the regime of laws in existence, the porous nature of Nigerian boarders and corrupt boarder officials is a huge problem that hinders the effort to curb sex trafficking in Nigeria. The women and girls trafficked from Nigeria use Nigerian boarders to go to foreign countries.

It is therefore suggested that, there is need for better synergy by all concerned so as to bring about prompt prosecution and possible conviction to deter would be traffickers. Most importantly, there should be rigorous campaign and education by human rights activists and NGO's on the evils of this inimical practice. People should be sensitized in the rural areas where innocent girls are lured away from their homes. It cannot be overlooked though that some level of success has been recorded in Nigeria in the fight against trafficking.

\section{References}

Agatise, E. (2005). Women Trafficking From West Africa to Europe, Cultural Dimensions and Strategies. Retrieved January 1, 2011, from http://www koed.hu/mozaik/5/esohe.pdf

Child's Right Act. (2004). Laws of the Federation of Nigeria (Chapter C50).

Criminal Code. (2004). Laws of the Federation of Nigeria (Chapter C38).

Egede, S. C. (Eds.). (n. d.). Access to Justice for Trafficked Persons in Nigeria (p. 12). Lagos: A Handbook for Legal Actors and Assistance Providers, NAPTIPP.

Gbadamosi, O. A. (2006). International perspectives and Nigerian laws on human trafficking. Retrieved February 2, 2013, from http://www .justice and democracy.org/trffic\%20Bk.p

Immigration Act. (2004). Laws of the Federation of Nigeria (Chapter 11).

International Labour Office. (2005). A Global Alliance against Forced Labour. International Labour Conference Report, 1(B), 51.

IRIN. (2005). Broken Bodies, Broken Dream, Violence Against Women Exposed (p. 87). Kenya: A United Nations OCHA/IRIN Publication.

Penal Code (Northern States) Federal Provisions Act. (2004). Laws of the Federation of Nigeria (Chapter P3).

Rossi, A. (2000). Trafficking in Human Beings Especially Women and Children in Africa, Innocents Insight, Florence (No. 6).

\section{Notes}

Note 1. United States Department of State, 2005.

Note 2. Human Trafficking, Trafficking of Humans Coalition Against Human Trafficking. http:/www.catwinternational.org/ accessed on 23/9/2011.

Note 3. Human Trafficking in Nigeria: Root Causes and Recommendations. 1478448 human trafficking. Pdf adobe rReader. accessed on 23/9/2012

Note 4. Prostitution Research \& Education, http:/www. Prostitution research. com/ laws/000163. Html accessed on $23 / 9 / 2010$

Note 5. Wikipedia, Human trafficking in Nigeria, http://en.wikipedia.org/wiki/ Human _trafficking_in_Nigeria, accessed on $2 / 2 / 2013$

Note 6. Human Sex Trafficking: Exploitation of Women and Children, http://www.articlesbase.com/womens-issues-articles/human-sex-trafficking-exploitation-of-women-and-children -935512.html?utm_source=google\&utm_medium =cpc\&utm_campaign=ab_paid_12\&gclid=cmugvvos7bucfsgq paodqiaadg, accessed on 2/2/2013

Note 7. Also commonly known as NAPTIP ACT.

Note 8. A Law to Amend Some of the Provisions of The Criminal Code Law, cap 48 Laws of Bendel State 1976 as applicable to Edo State, 2000. 
Note 9. Section 30

Note 10. Section 11

\section{Copyrights}

Copyright for this article is retained by the author(s), with first publication rights granted to the journal.

This is an open-access article distributed under the terms and conditions of the Creative Commons Attribution license (http://creativecommons.org/licenses/by/3.0/). 